\title{
Why a New Urbanist research agenda is needed
}

\section{Emily Talen}

This book seeks to answer the question: what do we need to know about the success, failure, and future prospects of creating walkable, diverse urbanism? Separating out what we already know from what we don't know, the book moves forward with a research agenda aimed at helping to sustain the movement for walkable, diverse urbanism - that is, New Urbanism. As it turns out, there is a lot we still need to know about creating and sustaining good cities.

New Urbanism is a statement of principles about how cities ought to develop. As laid out in the movement's Charter, cities should be walkable, mixed in use, socially diverse, and transit-served. ${ }^{1}$ There are no exact prescriptions for things like density, housing type, and architectural style, but for other key aspects, the objective is unambiguous - cities and neighborhoods should be pedestrian- and transitoriented rather than car-oriented, and they should be diverse (along multiple dimensions) rather than homogeneous. A set of ideals based on these fundamentals began to congeal in the 1990s, and an organization was formed (the Congress for the New Urbanism), a Charter was written, and conferences were convened. Many proponents understood that these principles were part of a long-standing, well-articulated school of thought about urban problems and their solutions that extended back to the 19 th century.

In the decades following, New Urbanists worked hard to become mainstream. In the 1990 and into the first decade of the 2oth century, there were still prominent people who needed convincing that sprawl was a problem and that urban walkability was fundamental. Some rejected the validity of normative idealizing in general. Now, however, it seems that urban planners, environmentalists, elected leaders, and citizens of many stripes accept the validity of New Urbanist goals-that promoting cities that are transit-served, bike-friendly, walkable, environmentally benign, well-serviced, and socially diverse are worthy objectives. On the academic side, scholars have largely moved beyond debates about historicism, architectural weaknesses, and environmental determinism-topics that tended to hover around the idiosyncracies of isolated projects like Seaside and Celebration in Florida. That research was unsatisfying to begin with because it offered little in the way of pragmatic alternative. 


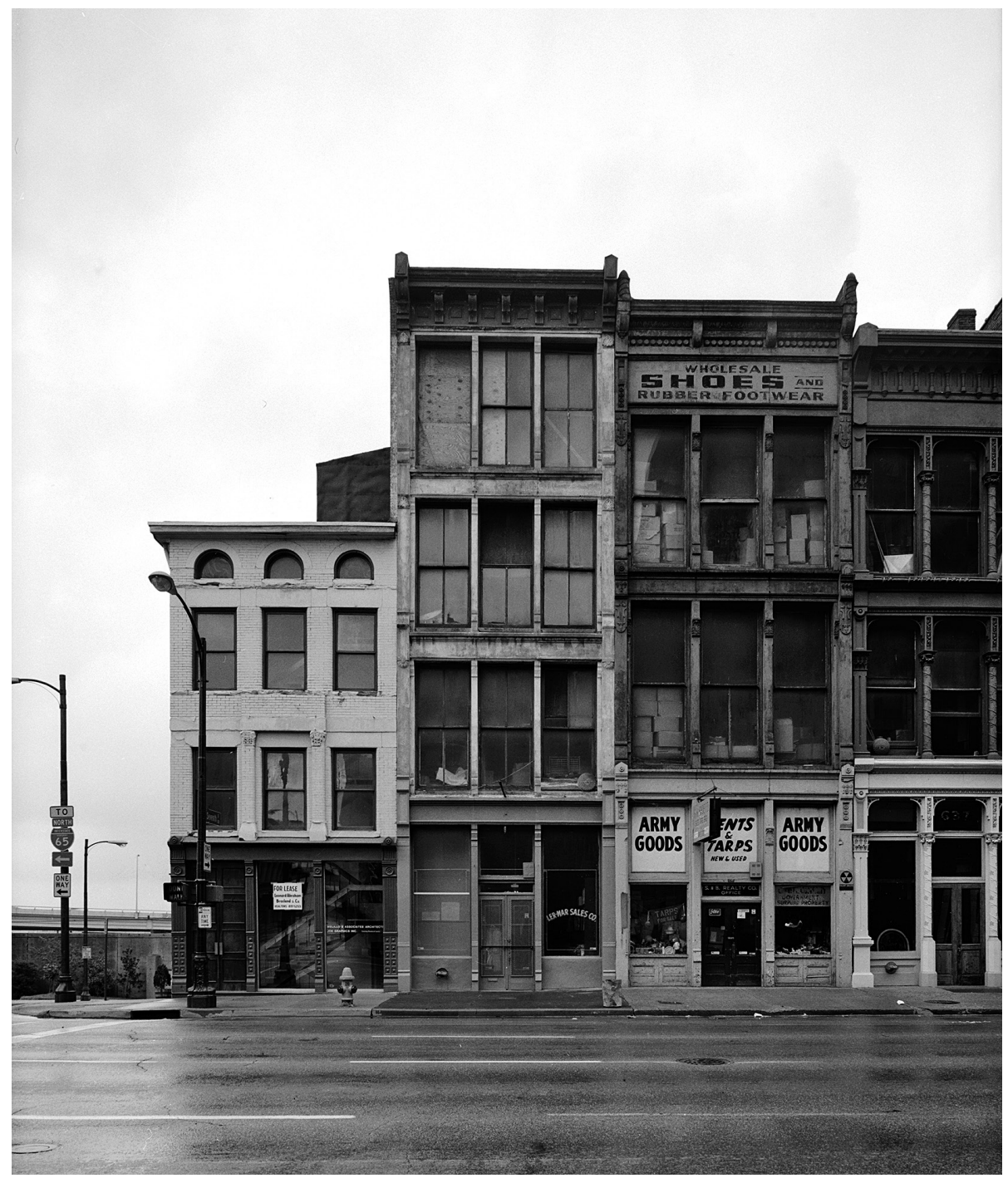

Source: https://commons.wikimedia.org/wiki/File:601-643_Main_Street,_north_side_of_street;_view_of_ south_(front)_sides_of_buildings_-_Main_Street,_600_and_700_Block_(Buildings),_Louisville,_Jefferson_ County,_KY_HABS_KY,56-LOUVI,10-14.tif

Figure 1.1 Main Street, Louisville, KY, c. 1933 (HABS, public domain). Louisville, KY is the site of the 2019 Congress for the New Urbanism conference

Acceptance of the legitimacy of New Urbanism's normative ideals means that debates surrounding New Urbanism no longer have to be about the worth of first principles (like the need for walkability), but instead can shift their focus to uncovering the roadblocks to achievement. As it turns out, however, some of the 
entrenched roadblocks signify that acceptance has not been strong enough to challenge existing policy. Political will is required-a will that depends on a rock-solid body of evidence supporting the necessary reforms-that cities should change their zoning, that funding should cease prioritizing highways, that housing should be integrated, that low-density sprawl should be stopped in its tracks.

Stronger research can play a role in stimulating these policy changes, but we also need more robust analysis about when, where, and why implementation falls short and what can be done about it. Some very basic questions remain unanswered. We still need to know-in a more rigorous way-whether, and how, New Urbanist principles are ever achieved, whether the outcomes associated with a particular implementation strategy are providing environmental, social, and economic benefits as claimed, and what the best strategy might be for fulfilling each goal. And while these are the kinds of questions that result in a progression of ideas and do not threaten the legitimacy of underlying ideals - that is, that cities should be walkable, compact, and diverse-the research questions that need to be answered have become more complex. As the authors explore in these chapters, new challenges are constantly asserting themselves.

The researchers writing in this book have accepted that the principles of New Urbanism are part of a long-standing, well-articulated school of thought about urban problems and their solutions, but they argue that both the assumptions on which New Urbanist arguments have been articulated and the problems of implementation that New Urbanists encounter need more examination. A good number of them are also seeking solid evidence backing New Urbanist claims-evidence that could be leveraged to make the case for New Urbanism more convincing.

The set of research questions identified in these chapters are intended to carry the movement forward. A wide array of topics are covered, from big picture concerns about the need for more theory development, to more bread and butter topics like sustaining urban retail and encouraging multi-modal transportation. The authors explore research needs from the social, environmental, and economic sides of New Urbanism, from small-scale DIY tactics to large-scale policy platforms like the UN's New Urban Agenda, from zoning reform to autonomous vehicles to climate change. New Urbanism is a large topic, and the research needed to sustain it is equally large. Readers will find that each chapter frames the research agenda by first laying out where we've been on a particular topic as a way of setting the stage. (A note on terminology: some authors use the term "New Urbanism" while others are more inclined to simply refer to "urbanism". Either way, the subject is the sameidentifying the research needed to advance the normative goal of producing human settlements that are walkable, diverse, and compact.)

Cliff Ellis starts things off with his deep dive into the theoretical terrain of New Urbanism. As New Urbanists forged ahead with their design ideals and their policy recommendations and programmatic wants, there was never sufficient time to lay the theoretical groundwork. What is needed, then, is vigorous reflection on the 
moral and political ramifications and underpinnings of the movement. Ellis refers to this as "intellectual capital," which he views as essential for helping to sustain the movement against modernist ideologies intent on articulating free-wheeling, ego-driven alternatives to the common sense of walkable urbanism. This includes understanding New Urbanism's political needs, finding a workable definition of "authenticity" in design, and grappling with the role of precedent. There are no easy answers-but we need to activate scholars who are willing to do the necessary complex thinking.

Donovan Finn and Gordon Douglas also grapple with theoretical issues as they lay out the research needs of DIY urbanism. The approach of DIY is much aligned with New Urbanism, but the authors worry about the implications of a mainstream movement like New Urbanism conjoining with the counter-cultural edginess of DIY tactics. We need to know how marginalized groups are faring in these efforts. New Urbanism needs to continually counter gentrification and displacement pressures, but before strategies can be worked out, we need research that gives an explicit picture of what the terrain is. How can New Urbanists encourage interventions that work, while discouraging ones that don't work-without being too heavy-handed?

The next two chapters-Conrad Kickert on retail and Wes Marshall on transportation-are less theoretical but no less foundational. Both topics are central to the success of New Urbanism. Retail has been undergoing dramatic shifts, such that urbanists do not have the luxury of relying on mom and pop stores to activate a vibrant retail corridor at the heart of a neighborhood. Kickert hones in on what is at stake and what we need to figure out. He asks: what lies at the root of retail success in urban neighborhoods, and what do the forces of agglomeration, stratification, and compatibility have to do with it? He finds that not enough is known about retail dynamics and what an appropriate mix of uses ought to be. He also finds that the current focus on abstract demographics and spreadsheet analysis has been damaging, and that we need to learn from our European counterparts. We also need a better understanding of the relationship between retail revitalization and gentrification.

Research needs on the transportation front are equally compelling. Those aligned with New Urbanism know that cities should be multi-modal, but given the sea change needed in policy decision-making, we need strong support documenting the environmental, economic, and social benefits resulting from "a more walkable world." Marshall laments the "archaic conceptual foundations" of transportation planning-how models for predicting demand (and therefore funding) are outdated and unsupportive of walkable urbanism. We need rigorous research to change these fossilized metrics and worn-out attitudes. This need is perpetual, as with each new technological fix-autonomous vehicles being the latest-unintended consequences lie dormant. Research into past experience with technological fixes (like cars) needs to be spotlighted. 
Kelly Turner takes on the environmental track record of New Urbanism, pointing out that much more evidence is needed. Do the principles of New Urbanismas currently implemented-improve environmental outcomes and help climate change adaptation and mitigation? New Urbanists assume so, and there is evidence in their favor-but it needs to be more aligned with climate science. In fact, there is very little evidence on how New Urbanist design is helping with microclimate regulation, especially its ability to offset heat impacts. The good news, as Kelly points out, is that New Urbanist developments are ready-made field stations, where presumed connections between design and sustainability can be tested.

Two chapters probe the social aspects of New Urbanism-and take stock of what we still don't know about the social outcomes of the movement. Conventional wisdom would posit that New Urbanist neighborhoods lack diversity-but is that true? And to what degree? Subsidized housing in Hope VI mixed-income neighborhoods is racially diverse, but what about market rate housing that aspires to New Urbanist principles and integrates housing types, sizes, and price points? April Jackson refers to the need for "cultural competency," where practitioners increase their awareness and acquire the skills needed to foster inclusion in community design. Where has that already been tried, and has it been working to effectively arrive at truly diverse neighborhoods? Jackson makes the further point that New Urbanists need to know how best to support positive social interactions among residents.

Sungduck Lee considers the under-researched principle of social sustainability, which is usually overshadowed by environmental and economic definitions of sustainability. Yet New Urbanism is as much a social movement as an environmental or economic one, and we need research that better connects design principles and social outcomes. Lee offers an evaluative framework for achieving that, arguing that researchers need to find measurable indicators of social sustainability and apply them to New Urbanist developments. It helps that the Charter already lays out the social ideals that can help with the development of assessment criteria, but researchers need to operationalize these ideals and find better ways to quantify social effects.

Matthew Hardy urges researchers to spend more time on the effects of urban growth. This includes everything from infill development to expansion at the periphery to vertical growth and density-what urban forms, in different contexts, provide the best urban quality? He argues that there has been too much reliance on outdated engineering standards and not enough evidence based on post-occupancy research. Such studies would shed light on what is actually meant by "best practice" in design. To date, best practice is too often unsubstantiated, relying on concepts that are only weakly supported by the actual experience of living in a place.

The last two chapters take a more encompassing view of research needs. Michael Mehaffy uses the UN's New Urban Agenda as a framework, urging researchers to consolidate and disseminate what is known about successfully achieved urbanism. This entails the need to better define urbanism in its many dimensions, and then 
attach the appropriate level of understanding about what works and what doesn't. It is a call for better organization of research output. He also points to two issues that need special attention: the role of urban networks in supporting quality urbanism, and the central role played by public space-what are the "geometric parameters" of public space that improve urbanism?

Ajay Garde looks at the "future of urbanism" and the sticking points preventing us from a more widespread application of better forms of human settlement. We still lack a complete understanding of the barriers to walkable, transit-served urbanism, and whether the removal of those barriers would help us achieve better cities. Evidence is needed about the factors of successful mixed-use developments, the limits and potentials of zoning reform, and the impact of new transportation technologies like autonomous vehicles and shared-use mobility.

Research aimed at answering the questions these authors pose-combined with widespread dissemination of results - will be a key factor in New Urbanism's ability to maintain its course, which in the past decade has been a positive trajectory. As all academics know, the most important thing to get right in scholarly research is to ask the right question. Above all, a research question has to satisfy the "so what?" test-that is, is the question being posed worth being answered? Will anyone care? Fortunately, because New Urbanism is inherently practitioner-oriented, these questions are far from "academic" in the strict sense of the term. Each of the research agendas laid out here are solidly located in the "real" world of practicing urbanism.

As an official movement with its own Charter and an organization with a full-time staff headquartered in Washington, DC, New Urbanism enjoys renown and attention. Membership continues to grow, conferences are well attended, and publications asserting core values and detailing success stories keep coming. But New Urbanism is a work in progress, and researchers have the ability to exert some positive influence on the direction that implementation will go. The idea of concentrating rather than dispersing employment and services, increasing pedestrian access, clustering housing, and mixing land uses is widely shared. But while these goals seem like a common-sense response to the crisis of metropolitan fragmentation and decentralization, there is nothing easy about keeping the principles at the forefront.

It has always seemed to me that New Urbanism is a topic in need of sustained, rigorous scholarship-not just to give academics fodder for their publications, but as a way to keep the movement relevant. There is plenty of debate that happens internally within the movement-on listserves, at conferences-but these debates are not seen by the outside world. We need to keep research proactive and positive, offering something constructive so that New Urbanism can advance closer to achieving its stated aims. I believe this book will contribute to that effort. 
NOTE

1 The main precepts were formally laid out in various publications from the 1990s. The most prominent examples include: Calthorpe, P., 1993, The Next American Metropolis: Ecology, Community, and the American Dream. New York, NY: Princeton Architectural Press; Congress for the New Urbanism, 200o, Charter of the New Urbanism. New York, NY: McGraw-Hill; Duany, A. and Plater-Zyberk, E., 1991, Towns and Town-Making Principles. New York, NY: RizzolI; Katz, P., 1994, The New Urbanism: Toward an Architecture of Community. New York, NY: McGraw Hill; Kunstler, J. H., 1996, Home from Nowhere. New York, NY: Simon \& Schuster; Langdon, P., 1994, A Better Place to Live: Reshaping the American Suburb. Amherst, MA: University of Massachusetts Press. 